\title{
EXPLORATION OF THE POSSIBILITIES FOR THE PRODUCTION OF TABLEWARE FROM THE BRAN OF VARIOUS CEREALS
}

\begin{abstract}
Jüri OLT, Institute of Technology, Estonian University of Life Sciences, Tartu 51006, Estonia jyri.olt@emu.ee (corresponding author)

Kaarel SOOTS, Institute of Technology, Estonian University of Life Sciences, Tartu 51006, Estonia kaalrl.soots@emu.ee

Andres OLT, Institute of Veterinary Medicine and Animal Sciences, Estonian University of Life Sciences, Tartu 51006, Estonia, andres.olt@emu.ee

Vahur ROONI, Institute of Technology, Estonian University of Life Sciences, Tartu 51006, Estonia vahur.rooni@emu.ee

Biodegradable and compostable tableware is significantly more environment and nature friendly than disposable tableware and drinkware made of plastic. Tableware made of wheat bran, but also corn and rice bran is already commercially available. It is reasonable to use the by-products of the milling of also other cereals, like rye bran, barley bran and oat bran, for the production of tableware. The aim of this research was to explore the possibilities for the production of tableware and drinkware from the by-products of the milling of wheat and also other cereals like rye and oat bran. In order to achieve the aim, compacts were moulded from rye bran and oat bran and mixtures of bran (wheat bran and rye bran) using various work modes. The moulding of the compacts included different temperatures of the mould, moulding durations and compressive forces. The mechanical properties like density and flexural strength of the compacts were determined and the compostability of the compacts was studied. The test bodies were placed inside a compost bin to check their compostability and to determine the duration of composting.
\end{abstract}

Keywords: cereal milling by-products, bran, compostable tableware, mechanical properties, flexural strength.

\section{INTRODUCTION}

The mankind is currently living in an era of mindless overproduction and overconsumption. Every year the habited areas release about 8 million tons of plastic waste into bodies of water and thereafter the oceans (Tullo, 2018). The main polluters of the oceans are China, India, Indonesia, the Philippines, Thailand, Sri Lanka, Vietnam and Bangladesh (Walther et al., 2018; Jambeck et al., Macrae, 2015). These countries are characterised by relatively undeveloped waste handling systems. However, the waste problems are topical not only in these countries, but also in Europe and America. Some countries do not use waste containers for storing ordinary household waste, not to mention the lack of containers for various types of waste. In addition to the packagings that pollute the living environment (e.g., packagings of chips and sweets), packagings of various beverages (e.g., bottles), filtered tobacco products (e.g., cigarette stubs), balloon sticks, drinking straws, plastic cotton buds and plastic bags, also disposable tableware (cups with various sizes, plates, forks, knives, spoons, skewers) constitute a significant amount of the waste. Such tableware does not decompose when it reaches natural environment; it becomes a source of pollution. The decomposing of plastic will take a long time, whereby poisonous compounds shall be released (Shah et al., 2008, Tosin et al., 1998). Unfortunately, the cardboard plate is not significantly more environment-friendly compared to the plastic plate. The cardboard plate is covered with a thin plastic layer, which means that the plate does not qualify as biowaste and it cannot be processed. The cardboard plate qualifies as household waste, which is sent to a landfill or used as a combustible material in an incinerator.

The consumption of disposable plastic tableware increases drastically in the summer, especially during the season of picnics and barbecues. At the same time, environment-friendly biodegradable tableware has become commercially available, which does not pollute when it reaches the environment; however, the price is higher than that of plastic tableware.

Consumers have started to use alternative biodegradable tableware (Willett, Howell, 2017). However, it should be noted that they may not be completely degradable in nature as they contain microplastics (Siracusa et al., 2008). Biodegradability means that the material is capable of undergoing aerobic and anaerobic degradation which results in the formation of $\mathrm{CO}_{2}, \mathrm{H}_{2} \mathrm{O}$, methane, biomass and mineral salts. Biodegradable material may not be compostable. The composting process consists of the decomposing of organic waste by the microbes, i.e., the production of compost.

Therefore, compostable products, tableware and drinkware are the most nature-friendly ones (Satyanarayana et al., 2009 Song et al., 2009; Gurunathan et al, 2015). Fieschi and Pretato (2018) claim that the use of biodegradable and compostable tableware will reduce ecological footprint. Such products may be produced from the agricultural byproducts, namely the by-products of post-harvest processing, which are of natural origin and most probably will decompose completely in nature without polluting it. These by-products may include the bran and chaff of cereals, corn

Copyright (C) 2019 The Authors. Published by Vytautas Magnus University. This is an open-access article distributed under the terms of the Creative Commons Attribution License (CC BY 4.0), which permits unrestricted use, distribution, and reproduction in any medium, provided the original author and source are credited. 
or rice. According to a source (http://www.atrileaf.com), the raw materials may include sugar cane (http://www.xmjeafer.com) and tree leaves. Wheat bran is the most well-known cereal bran, but also the possibilities for the production of tableware from other brans like rye bran, barley bran and oat bran should be studied. Table 1 shows the technical characteristics of the by-products of milling cereals.

Table 1. Characteristics of the by-products of milling cereals

\begin{tabular}{lccccc}
\hline Characteristics & Oat bran & Barley bran & Corn bran & Wheat bran & Rye bran \\
\hline Dry matter, $\%$ & 86 & 86 & 88 & 86 & 86 \\
\hline Raw fibres, $\%$ & 18.5 & 15.5 & 11.5 & 9.7 & 10.0 \\
\hline Raw ash, $\%$ & 5.0 & 5.5 & 4.0 & 5.5 & 5.0 \\
\hline
\end{tabular}

It can be claimed on the basis of the data from Table 1 that the bran of cereals is quite similar in terms of the content of dry matter and raw ash, only oat bran contains about twice the amount of raw fibres when compared to wheat bran. For the purposes of this study, it is important to know the raw material base for the production of tableware from bran or which developments have occurred during the century in terms of the growing areas of cereals and harvests from cereal fields. The growing areas of the most important cereals in Estonia have been given in Table 2.

Table 2. Growing areas of cereals $\left(\times 10^{3} \mathrm{ha}\right)$

\begin{tabular}{lcccc}
\hline Cereal & 2001 & 2010 & 2015 & 2017 \\
\hline Total growing area & 274.1 & 275.3 & 350.4 & 350.6 \\
\hline including: & & & & \\
\hline - rye & 20.9 & 12.6 & 14.3 & 13.3 \\
\hline - winter wheat & 25.5 & 50.6 & 97.8 & 102.4 \\
\hline - summer wheat & 34.1 & 68.8 & 71.9 & 67.3 \\
\hline - barley & 134.3 & 103.8 & 130.3 & 38.3 \\
\hline - oat & 48.1 & 30.4 & 24.4 & 33.6 \\
\hline - buckwheat & 0.7 & 0.3 & 1.4 & 5.3 \\
\hline
\end{tabular}

Table 2 shows that the growing areas of cereals have increased in general, whereby the growing areas rye, barley and oat have decreased and the growing areas of wheat have increased. This reassures that the cultivation of cereals will not cease in Estonia in the near future. The harvests of cereals should be pointed out to obtain a better overview (Table 3 ).

Table 3. Cereal harvests in Estonia $\left(\times 10^{3}\right.$ tons $)$

\begin{tabular}{lcccc}
\hline Cereal & 2001 & 2010 & 2015 & 2017 \\
\hline Total harvest & 558.1 & 678.4 & 1535.3 & 1311.9 \\
\hline Including: & & & & 52.4 \\
\hline - rye & 42.9 & 25.0 & 54.7 & 481.4 \\
\hline - winter wheat & 57.3 & 148.5 & 518.5 & 231.9 \\
\hline - summer wheat & 75.6 & 179.1 & 294.1 & 402.9 \\
\hline - barley & 270.0 & 252.7 & 551.5 & 89.4 \\
\hline - oat & 91.4 & 54.5 & 67.8 & 3.4 \\
\hline - buckwheat & 0.6 & 0.1 & 1.2 & \\
\hline
\end{tabular}

Table 3 shows that the cereal harvests have more than doubled during this century. The harvest of oat has remained almost the same, the harvest of rye has somewhat increased, but the greatest increase is in the harvest of wheat. According to global trends, the harvests of wheat, corn, rice and rape are increasing while the harvests of rye and oat are somewhat decreasing. About 100,000 tons of cereals are milled annually in Estonia. The milling of cereals results in $22 \pm 2 \%$ or 20,000-24,000 tons of bran.

The compressing of the by-products of cereals involves the following processes: pressure is applied to the compressible material, the temperature of the compressible material is raised to predetermined level, temperature and pressure breaks the ligneous cell structure of the plant, whereby the heat softens the lignin in the material and lignin bonds the loose particles of the compressible material (Pietsch, 2002; Olt, Laur, 2009).

It is known from sources (Singh, Satapathy, 2018) that wheat bran contains on average 45.8\% (22.8-59.6\%) neutral fibres (cellulose, hemicellulose, lignin), 13.6\% (8.1\%-18.7\%) acid fibres (cellulose, lignin) and 3.8\% (1.9\%$5.2 \%)$ lignin. Another source (Sauvant et al, 2002) claims that the content of neutral fibres is on average $47.5 \%(40.3 \%-$ $55.0 \%)$, acid fibres $13.7 \%(11.1 \%-17,3 \%)$ and lignin $4.0 \%(3.1 \%-4.9 \%)$. Sources do not contain such information on other brans. At the same time, it is known that wheat straws contain $7.94 \%$ of lignin and other straws contain $5.05-8,76 \%$ (Raud et al., 2016; 2018). This variation in the lignin content of bran and straws can be accounted for by the fact that bran contains starch and, therefore, it must contain less lignin than the straws (Soots et al., 2019). However, ground straws can be added to bran in order to reduce the cost price of manufacturing of tableware. Straws are also a lignocellulose material, but the price is considerably lower compared to bran. 
The introduction of compostable products, including tableware, is feasible only if their mechanical properties are comparable to the mechanical properties of disposable tableware made from cardboard and plastic. The flexural strength of the material suitable for the production of compostable tableware must be at least equal to the flexural strength of plates made from wheat bran, which is $\delta_{\mathrm{fm}}=9.98 \mathrm{~N} \mathrm{~mm}^{-2}$ (Soots et al., 2019).

A compostable tableware production technology according to the patent document US9517578 contains, for example, the following steps: bran with fraction $0.01-2.80 \mathrm{~mm}$ and moisture content of at least $14 \%$ are mixed; then measured into a moulding, which contains a matrix and a mark and whose temperature is $120{ }^{\circ} \mathrm{C}$ and which is used to compress the material up to the pressure $10 \mathrm{MPa}$; the compression results in a product with the density of $1.4 \mathrm{~g} \mathrm{~cm}^{-3}$. The technical solution protected by this patent document was taken as a model for this study.

In order to call the product, in our case the tableware, completely compostable, it must meet the requirements (DIN EN 13432 and/or ASTM D6400 and ASTM D6868). Both of these specifications require that biodegradable/compostable products must degrade completely in the composting environment within a certain time and they are not allowed to leave any hazardous residues.

It became clear that there were no sources about the use of the by-products of the milling of other cereals (besides wheat bran), like rye, oats and barley for the production of compostable tableware. Therefore, the aim of this study is to explore the possibilities for the production of compostable tableware from other cereal brans.

\section{MATERIAL AND METHODS}

In addition to the already known wheat bran, the materials of this study included rye bran and oat bran. It was not possible to obtain barley bran from the market nor cereal mills. The characteristics of materials were studied separately and in the following mixtures: 1 ) mixture of wheat bran and oat bran 50\%/50 \% by mass; 2) mixture of rye bran and oat bran $50 \% / 50 \%$ by mass; 3 ) mixture of rye bran and wheat bran $50 \% / 50 \%$ by mass.

The sieve analysis of the materials was performed using the sieve analysis device PKФ-1, which contained sieves with round apertures with the following diameters $10,7,5,3,2.5,2,1.5,1,0.5$ and $0.25 \mathrm{~mm}$. The balance used was Kern EMB 500-1, which has a measuring range up to $500 \mathrm{~g}$ and has a precision of $d=0.1 \mathrm{~g}$.

The filter bag method was used to perform the fibre analysis of the materials to determine the content of hemicellulose, cellulose and lignin in the material. The analysis was performed using the fully automatic fibre analyser ANKOM 2000. Incineration for the determination of insoluble lignin was performed according to laboratory analytical procedure NREL/TP-510-42622 (Determination of Structural Carbohydrates and Lignin in Biomass) given in the NREL (National Renewable Energy Laboratory) technical report.

A three-point flexural test according to the standard ISO 178:2010 was performed to measure the mechanical properties of tableware using the test device Instron 5969. Test bodies or compacts were made to perform the flexural strength test. The authors of this study consider the three-point flexural test similar to real life loads which are applied to tableware upon using it.

Compacts with the following diameters were made to perform the flexural strength test and to determine density: diameter $D_{p}=50 \mathrm{~mm}$, thickness $b_{p}=2.5 \mathrm{~mm}$. The compacts were produced in the hydraulic press using a pre-heated steel mould. The mould was pre-heated in the muffle furnace Nabertherm $\mathrm{N} \mathrm{7/H}$, whereby the minimal heating time before the next compression was 15 minutes.

The modes for producing compacts from the studied materials were the following:

1) Temperatures $T=150,200$ and $250{ }^{\circ} \mathrm{C}$ (which originate from lignin's melting temperature of $200 \pm 50{ }^{\circ} \mathrm{C}$ ), whereby the temperature of the mould was measured using the thermometer contained in the furnace;

2) It is generally known that unit pressure $\sigma_{c}$ is proportional to compressive force $F$ and inversely proportional to cross-section $S$, or

$$
\sigma_{c}=\frac{F}{S}
$$

and taking into account that the cross-section of the test body is $S=\pi \cdot D_{p}{ }^{2} / 4$, compressive force can be determined as follows

$$
F=\frac{1}{4} \cdot \pi \cdot D_{p}^{2} \cdot \sigma_{c}
$$

and when $D_{p}=50 \mathrm{~mm}$ and $\sigma_{c}=10 \mathrm{MPa}$, the compressive force amounts to $F=19625 \mathrm{~N} \approx 2 \mathrm{tf}$. In the planned test, the compressive force was $F=2,15$ and $30 \mathrm{tf}$, whereby the force was applied for 3 seconds;

3) Duration for the stationary application of the force $t=60,90,120$ and $3+120 \mathrm{~s}$.

A hydraulic press was used as the power unit for the manufacturing of test bodies or compacts and a specially made mark and matrix were used as tools. The mark and the matrix were made for the production of disc-shaped compacts with the diameter of $50 \mathrm{~mm}$. At least three repetitions of the manufacturing of compacts were performed in each work mode. 


\section{RESULTS}

The studied material (rye bran, oat bran and wheat bran) were supplied by the company Tartu Mill AS. The results of the sieve analysis of the material have been given in Table 5.

Table 5. Results of the sieve analysis

\begin{tabular}{cccc}
\hline Parameter & Oat & Rye & Wheat \\
\hline Fineness, $\mathrm{mm}$ & 1.15 & 1.97 & 1.79 \\
\hline
\end{tabular}

According to the patent document US9,517,578 A, the fractional composition of bran must be in the range of 0.01$2.8 \mathrm{~mm}$. The results of the sieve analysis showed that the fractional compositions of all the brans supplied by Tartu Mill AS remain within this range.

The fibre analysis was performed in the Laboratory of Biofuels of the Institute of Technology of the Estonian University of Life Sciences. The results have been given in Table 6.

Table 6. Results of fibre analysis

\begin{tabular}{cccc}
\hline Material & Hemicellulose & Cellulose & Lignin \\
\hline Wheat bran & $30.35 \pm 0.16$ & $10.15 \pm 0.12$ & $5.46 \pm 0.03$ \\
\hline Oat bran & $7.83 \pm 1.10$ & $3.40 \pm 0.35$ & $11.22 \pm 0.37$ \\
\hline Rye bran & $30.37 \pm 0.10$ & $5.55 \pm 0.14$ & $4.26 \pm 0.05$ \\
\hline
\end{tabular}

The fibre analysis showed that oat bran contains significantly higher levels of lignin, but also starch compared to wheat bran and rye bran.

The following part presents only the flexural strengths of compacts obtained in modes which resulted in highquality compacts, for which the material did not exit the mould and for which the flexural strength of the compact is equal to or higher than that of the commercially available plate made of wheat bran. Table 7 presents the data on the compacts made from rye bran and Table 8 shows the data on the compacts made from wheat bran. The production modes $(T, F, t)$ for the compression of compacts were observed strictly. A muffle furnace was used to achieve the pre-determined temperature. Here it must be pointed out that as the initially planned temperature of $250{ }^{\circ} \mathrm{C}$ did not have an effect on the mechanical properties of the compacts, tests were not continued using this temperature. Therefore, heating to $250{ }^{\circ} \mathrm{C}$ is not necessary. The compressive force $F=2 \mathrm{tf}$ did not ensure required flexural strength. The compacts of oat bran did not achieve the flexural strength of $10 \mathrm{~N} \mathrm{~mm}^{-2}$. Therefore, oat bran is not suitable as the raw material for the production of tableware.

Table 7. Data on the compacts made from rye bran

\begin{tabular}{cccc}
\hline Work mode & Flexural strength, $\mathrm{N} \mathrm{mm}^{-2}$ & Standard deviation & Standard error \\
\hline $150^{\circ} \mathrm{C}, 15 \mathrm{tf}, 60 \mathrm{~s}$ & 12.17 & 0.85 & 0.49 \\
\hline $150^{\circ} \mathrm{C}, 15 \mathrm{tf}, 90 \mathrm{~s}$ & 13.24 & 1.11 & 0.64 \\
\hline $150^{\circ} \mathrm{C}, 30 \mathrm{tf}, 90 \mathrm{~s}$ & 10.14 & 0.33 & 0.19 \\
\hline $200^{\circ} \mathrm{C}, 15 \mathrm{tf}, 60 \mathrm{~s}$ & 14.61 & 1.07 & 1.62 \\
\hline $200^{\circ} \mathrm{C}, 15 \mathrm{tf}, 90 \mathrm{~s}$ & 13.95 & 2.81 & 1.26 \\
\hline $200^{\circ} \mathrm{C}, 15 \mathrm{tf}, 120 \mathrm{~s}$ & 13.14 & 2.19 & 1.81 \\
\hline $200^{\circ} \mathrm{C}, 30 \mathrm{tf}, 60 \mathrm{~s}$ & 10.69 & 3.14 & 1.04 \\
\hline $200{ }^{\circ} \mathrm{C}, 15 \mathrm{tf}, 3+90 \mathrm{~s}$ & 13.18 & 1.79 & \\
\hline
\end{tabular}

All flexural strengths listed in Table 7 remained in the range of 10.69-14.61 N mm${ }^{-2}$ and all of them were greater than $10 \mathrm{~N} \mathrm{~mm}^{-2}$; therefore, the parameters were sufficient. The most suitable work mode was $T=200{ }^{\circ} \mathrm{C}, F=15 \mathrm{tf}, t=60 \mathrm{~s}$.

Table 8. Data on the compacts made from oat bran

\begin{tabular}{cccc} 
Table 8. Data on the compacts made from oat bran & Flexural strength, $\mathrm{N} \mathrm{mm}^{-2}$ & $\begin{array}{c}\text { Standard } \\
\text { deviation }\end{array}$ & Standard error \\
\hline Work mode & 14.24 & 2.05 & 1.18 \\
\hline $200^{\circ} \mathrm{C}, 15 \mathrm{tf}, 3+90 \mathrm{~s}$ &
\end{tabular}

The compacts made from wheat bran (a material already known on the market) were done only to compare the compression results of rye bran and only in one work mode. The purpose of the test was to obtain a reference flexural strength of plates made from wheat bran by applying pressure to the compact for 3 seconds and by holding the mould together for 90 seconds after the removal of pressure. It became evident (Table 8) that the flexural strength of compacts made from rye bran is comparable to that of compacts made from wheat bran. Table 9 compares the data on the compacts made from wheat bran and rye bran in the same work mode. 
Table 9. Data on the compacts made from wheat bran, rye bran and oat bran $\left(T=200{ }^{\circ} \mathrm{C}, F=30 \mathrm{tf}, t=90 \mathrm{~s}\right)$

\begin{tabular}{lccc}
\hline Mixture & Flexural strength, N/mm & Standard deviation & Standard error \\
\hline Wheat bran and oat bran & 10.92 & 3.97 & 1.98 \\
\hline Rye bran and oat bran & 10.25 & 2.83 & 1.60 \\
\hline Rye bran and wheat bran & 12.18 & 1.99 & 0.99 \\
\hline
\end{tabular}

Here it must be noted that no compacts were achieved from oat bran that would have met the requirements in the planned work modes. Therefore, oat bran is not suitable for making compacts in these work modes. This may be caused by the high starch content of the oat bran.

Table 10. Average densities of the compacts $\mathrm{g} \mathrm{cm}^{-3}$

\begin{tabular}{cccccc}
\hline Wheat bran & Rye bran & Oat bran & $\begin{array}{c}\text { Mixture of rye bran } \\
\text { and oat bran }\end{array}$ & $\begin{array}{c}\text { Mixture of wheat bran } \\
\text { and oat bran }\end{array}$ & $\begin{array}{c}\text { Mixture of rye bran } \\
\text { and wheat bran }\end{array}$ \\
\hline 1.05 & 1.07 & 1.07 & 1.06 & 1.10 & 1.04 \\
\hline
\end{tabular}

Table 10 shows that the densities of compacts remained in the range of $1.03-1,10 \mathrm{~g} \mathrm{~cm}^{-3}$. Table 11 presents the summary of compacts made from rye bran and oat bran.

Composting of the test bodies. The composting of test bodies were started in the beginning of October 2018 (Figure 1) and it lasted till $17^{\text {th }}$ November 2018.

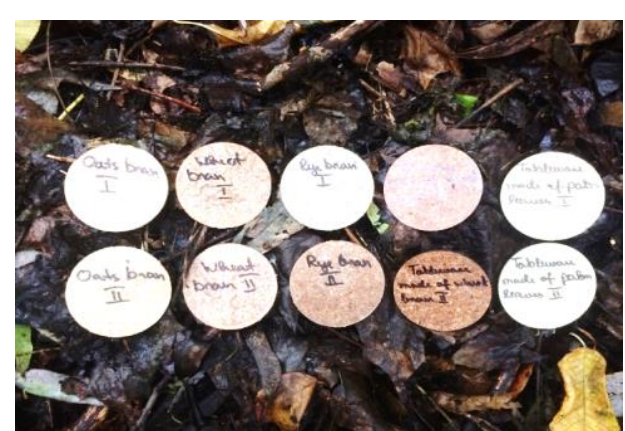

Figure 1. Test bodies in the composting area on $3^{\text {rd }}$ October 2018

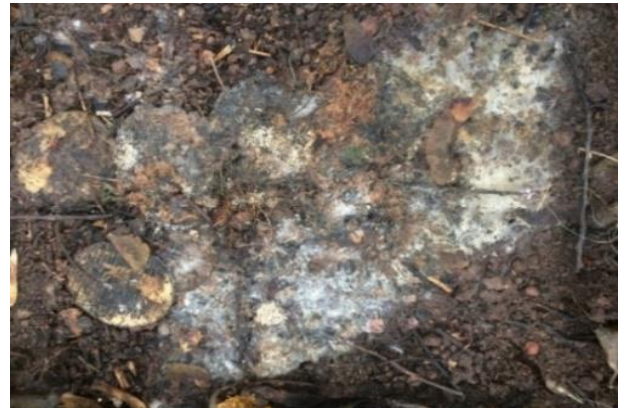

Figure 2. Test bodies in the composting area on $7^{\text {th }}$ November 2018 ( $35^{\text {th }}$ day)

The test bodies for the composting test were chosen among the compacts made from oat bran, wheat bran and rye bran these were placed into the compact bin. Composting was monitored weekly during the period (Figs 2, 3 and 4 ).

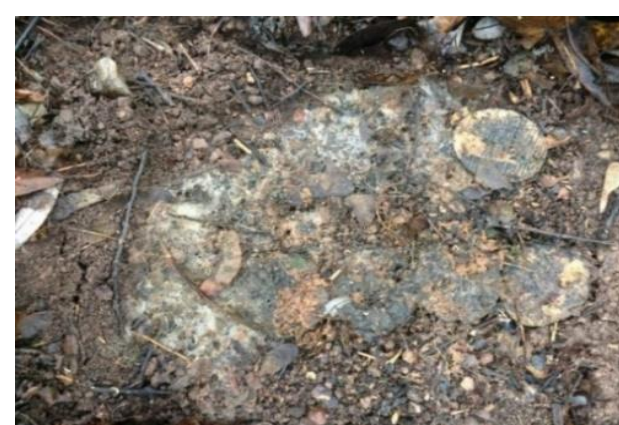

Figure 3. Test bodies in the composting area on $14^{\text {th }}$ November 2018 (42 $2^{\text {th }}$ day)

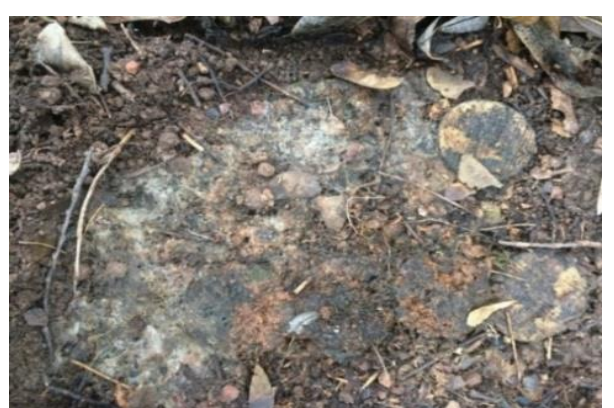

Figure 4. Test bodies in the composting area on $20^{\text {th }}$ November 2018 ( $48^{\text {th }}$ day)

Figure 4 illustrates that the test bodies meant for composting had already decayed and composted, which was anticipated as the raw material for the test bodies was a biological material.

\section{CONCLUSIONS}

1. Compostable tableware is mostly produced by compression of the by-products of cereal milling. In addition to wheat bran, rice bran and corn bran, tableware can be made of the bran of other cereals and their mixtures.

2. The growing area of cereals has increased to $c a 350,000$ ha during this century and the total harvest amounts to $1,535,300$ tons (year 2015). The milling of the cereal harvest gives about 20,000 tons of bran per year. If $40 \%$ of this amount is used to manufacture tableware, namely plates, then the total annual production volume may amount to 20 million compostable plates, which is a significant relief for the environment.

3. All of the 10 test bodies compressed from rye bran, wheat bran and oat bran composted completely within 48 days and left no hazardous residues.

4. The study showed that the flexural strengths of test bodies made from wheat bran slightly exceeded those made of rye bran and the mixture of rye bran and wheat bran. Therefore, the materials suitable for the production of tableware 
include, in addition to wheat bran, also rye bran and the mixture of rye bran and wheat bran. In order to reduce the cost price of production, the recipe may include ground cereal straws and chaff, which are also lignocellulose biological materials and compostable.

\section{REFERENCES}

1. ASTM D6400 - 12, 2012. Standard Specification for Labeling of Plastics Designed to be Aerobically Composted in Municipal or Industrial Facilities. Available at: https://www.astm.org/Standards/D6400.htm (accessed 18.07.2019)

2. ASTM D6868 - 17, 2017. Standard Specification for Labeling of End Items that Incorporate Plastics and Polymers as Coatings or Additives with Paper and Other Substrates Designed to be Aerobically Composted in Municipal or Industrial Facilities. Available at: https://www.astm.org/Standards/D6868.htm (accessed 18.07.2019)

3. DIN EN 13432, 2000. Requirements for packaging recoverable through composting and biodegradation. Available at: https://www.en-standard.eu/din-en-13432-requirements-for-packaging-recoverable-through-composting-and-biodegradation-testscheme-and-evaluation-criteria-for-the-final-acceptance-of-packaging-english-version-of-din-en13432/?gclid=EAIaIQobChMIi63nsCN3gIViuiaCh0vPgNdEAAYASAAEgJOavD_BwE (accessed 18.07.2019)

4. Elanchezhian C., Ramnath B. V., Ramakrishnan G., Rajendrakumar M., Naveenkumar V., Saravanakumar M. K. 2018. Review on mechanical properties of natural fiber composites. In: Proceedings of International Conference on "Materials, Minerals and Energy“(PMME), Vol. 5 (1), pp. 1785-1790 https://doi.org/10.1016/j.matpr.2017.11.276

5. Fieschi M., Pretato U. 2018. Role of compostable tableware in food service and waste management. A life cycle assessment study. Waste Management, Vol. 73, pp. 14-25 https://doi.org/10.1016/j.wasman.2017.11.036

6. Gurunathan T., Mohanty S., Nayak S. K. 2015. A review of the recent developments in biocomposites based on natural fibres and their application perspectives. Composites Part A: Applied Science and Manufacturing, Vol. 77, pp. 1-25. https://doi.org/10.1016/j.compositesa.2015.06.007

7. Jambeck J.R., Geyer R., Wilcox C., Siegler T.R., Perryman M., Andrady A., Narayan R., Law K.L. 2015. Plastic waste inputs from land into the ocean. Science, Vol. 347 (6223). https://doi.org/10.1126/science.1260352

8. Liu J., Jia C., He C. 2012) Rice straw and cornstarch biodegradable composites. AASRI Procedia, Vol. 3, pp. 83-88 https://doi.org/10.1016/j.aasri.2012.11.015

9. Macrae F. 2015. Eight million tons of plastic is dumped at sea each year... that's five whole bags-full for every foot of the world's coastline. Dailymail. Available at: https://www.dailymail.co.uk/sciencetech/article-2951256/Study-World-dumps-8-8-milliontons-plastics-oceans.html (accessed 18.07.2019)

10. Olt J., Laur M. 2009. Briquetting different kinds of berbaceous biomaterial. Proceedings of the International Scientific Conference "Engineering for Rural Develpoment", pp. 224-228.

11. Raud M., Tutt M., Olt J., Kikas T. 2016. Dependence of the hydrolysis efficiency on the lignin content in lignocellulosic material. International Journal of Hydrogen Energy, Vol. 41(37), pp. 16338-16343. https://doi.org/10.1016/j.ijhydene.2016.03.190

12. Sanjay M.R., Madhu P., Jawaid M., Senthamaraikannan P., Senthil S. 2018. Characterization and properties of natural fiber polymer composites: A comprehensive review. Journal of Clearner Production, Vol. 172, pp. 566-581. https://doi.org/10.1016/j.jclepro.2017.10.101

13. Satyanarayana K.G., Arizaga G.G.C., Wypych F. 2009. Biodegradable composites based on lignocellulosic fibers - An overview. Progress in Polymer Science, Vol. 34, pp. 982-1021. https://doi.org/10.1016/j.progpolymsci.2008.12.002

14. Sauvant D., Perez J.-M., Tran G. 2002. Tables of composition and nutritional value of feed materials. Wageningen Academic Publishers, INRA Editions'

15. Shah A.A., Abdul F.H., Ahmed H.S. 2008. Biological degradation of plastics: A comprehensive review. Biotechnology Advances Vol. 26 (3), pp. 246-265. https://doi.org/10.1016/j.biotechadv.2007.12.005

16. Singh Y.D., Satapathy K.B. 2018. Conversion of Lignocellulosic Biomass to Bioethanol: An Overview with a Focus on Pretreatment. International Journal of Engineering and Technologies, Vol. 15, pp. 17-43. https://doi.org/10.18052/www.scipress.com/IJET.15.17

17. Siracusa V., Rocculi P., Romani S., Rosa M.D. 2008. Biodegradable polymers for food packaging: a review. Trends in Food Science \& Technology, Vol. 19, pp. 634-643. https://doi.org/10.1016/j.tifs.2008.07.003

18. Song J.H., Murphy R.J., Narayn R., Davies G.B.H. 2009. Biodegradable and compostable alternatives to conventional plastics. Philosophical Transactions of the Royal Society B, Vol. 364, pp. 2127-2139. https://doi.org/10.1098/rstb.2008.0289

19. Soots K., Olt A., Olt J. 2019. Manufacturing technology and mechanical properties of biodegradable tableware made from cereal bran. Actual Tasks on Agricultural Engineering Conference Proceedings: 47th International symposium "Actual Tasks on Agricultural Engineering", Opatija, 5-7.03.2019. Ed. Kovačev, Igor; Bilandžija, Nikola. University of Zagreb, pp. $445-452$.

20. Tosin M., Degli-Innocenti F., Bastioli C. 1998. Detection of a Toxic Product Released by a Polyurethane-Containing Film Using a Composting Test Method Based on a Mineral Bed. Journal of environmental polymer degradation, Vol. 6 (2), pp. 79-90

21. Tullo A.H. 2018. Fighting ocean plastics at the source. Chemical \& Engineering news, Vol. 96 (16). Available at: https://cen.acs.org/materials/polymers/Fighting-ocean-plastics-source/96/i16

22. Walther B.A., Kunz A., Hu C-S. 2018. Type and quantity of coastal debris pollution in Taiwan: A 12-year nationwide assessment using citizen science data. Marine Pollution Bulletin, Vol. 135, pp. 862-872 https://doi.org/10.1016/j.marpolbul.2018.08.025

23. Willett K., Howell B. 2017. Using local invasive species and flora to manufacture collagen based biodegradable plastic tableware. In: Proceedings of the $21^{\text {st }}$ International Conference on Engineering Design (ICED17), Vol. 1: Resource-Sensitive Design | Design Research Applications and Case Studies, Vancouver, Canada, pp. 151-158. 